\title{
ASPEK HUKUM PIDANA TERHADAP INDIVIDU YANG MENGGUNAKAN IDENTITAS PALSU SEBAGAI SEORANG DOKTER (DOKTEROID)
}

\author{
Yohanes Firmansyah $^{1}$, Yana Sylvana ${ }^{2}$, Hanna Wijaya ${ }^{3}$, Michelle Angelika $\mathrm{S}^{4}$ \\ ${ }^{1}$ Program Studi Magister Hukum, Universitas Pembangunan Nasional Veteran, Jakarta \\ Email: yohanesfirmansyah28@gmail.com \\ ${ }^{2}$ Program Studi Magister Hukum, Universitas Pembangunan Nasional Veteran, Jakarta \\ Email: sylavanayana@gmail.com \\ ${ }^{3}$ Program Studi Magister Hukum, Universitas Pembangunan Nasional Veteran, Jakarta \\ Email: hannwijaya@yahoo.com \\ ${ }^{4}$ Program Studi Magister Hukum, Universitas Pembangunan Nasional Veteran, Jakarta \\ Email: michelleangelika111@gmail.com
}

Masuk : 04-10-2020, revisi: 27-10-2020, diterima untuk diterbitkan : 31-10-2020

\begin{abstract}
Health and medicine is a branch of science that aims to optimize and improve the health level of the public and individuals in order to improve the quality of life from individuals to communities. Medical and health education takes a long time and often costs a lot of money. Ironically, in the field there have been many incidents of persons pretending to be health workers, especially doctors (Dokteroid) without qualified competence. The problem raised in this study is how the legal aspects of a false identity as a doctor and the criminal aspect of the practice of medicine by a fake doctor (docteroid). The results of this study found that the use of a fake identity as a doctor and its criminal aspects has been regulated in Law Number 29 of 2004 concerning Medical Practice with a description of the criminal code contained in Articles 29 (1), 31 (1), 32 (1), 36, 73 (1), 73 (2), 41 (1), 42, 46 (1), and Article 51, as well as criminal regulations for physicians who practice illegal medicine as regulated in Articles 77 and 78 which contain evidence of violations of the provisions. in Articles 73 (1) and 73 (2) the threat of imprisonment for 5 years and a maximum fine of Rp. 150,000,000.00. On the other hand, law enforcement against cases of fake doctors who practice medicine uses preventive criminal law, namely prevention before a crime occurs by socialization and training as well as repressive criminal law in the form of actions to eradicate crimes based on reports by the public. The role of the community, law, apparatus, facilities, and culture is a factor that plays an important role in optimizing preventive action for docteroid cases
\end{abstract}

Keywords: health law; doctoroid; Doctor education; criminal law; Law of the Republic of Indonesia Number 29 of 2004 concerning Medical Practice

\begin{abstract}
ABSTRAK
Kesehatan dan kedokteran merupakan sebuah cabang ilmu pengetahuan yang bertujuan untuk mengoptimalkan dan meningkatkan taraf kesehatan masyarakat dan individu guna meningkatkan kualitas hidup individu dan masyarakat. Pendidikan kedokteran dan kesehatan ditempuh dengan waktu yang tidak singkat dan seringkali memakan biaya yang cukup besar. Ironisnya, di lapangan banyak sekali kejadian mengenai oknum yang berpura-pura menjadi tenaga kesehatan khususnya dokter (dokteroid) tanpa kompetensi yang mumpuni. Permasalahan yang diangkat dalam penelitian ini adalah bagaimana aspek hukum dari identitas palsu sebagai dokteroid dan aspek pidana dari pelaksanaan praktik kedokteran oleh dokteroid. Hasil penelitian ini menemukan bahwa penggunaan identitas palsu sebagai dokteroid dan aspek pidananya telah diatur dalam Undang-Undang Nomor 29 Tahun 2004 Tentang Praktik Kedokteran dengan uraian pidana tertuang dalam Pasal 29 (1), 31 (1), 32 (1), 36, 73 (1), 73 (2), 41 (1), 42,46 (1), dan Pasal 51, serta peraturan pidana bagi dokteroid yang menjalankan praktik kedokteran yang illegal diatur dalam Pasal 77 dan Pasal 78 yang berisikan adanya bukti pelanggaran terhadap ketentuan di Pasal 73 (1) dan 73 (2) dengan ancaman penjara 5 tahun dan denda uang maksimal Rp. 150.000.000,00. Disisi lain, penegakan hukum terhadap kasus dokter palsu yang melakukan praktik kedokteran menggunakan hukum pidana preventif yaitu pencegahan sebelum tidak kejahatan terjadi dengan sosialisasi dan pelatihan serta hukum pidana represif yang berupa tindakan untuk memberantas kejahatan berdasarkan adanya laporan oleh masyarakat. Peran masyarakat, hukum, aparat, fasilitas, dan kebudayaan adalah faktor yang berperan penting dalam optimalisasi tindakan pencegahan kasus dokteroid
\end{abstract}

Kata Kunci: hukum kesehatan; dokteroid; Pendidikan dokter; hukum pidana; Undang-Undang Republik Indonesia Nomor 29 Tahun 2004 tentang Praktik Kedokteran 


\section{PENDAHULUAN}

\section{Latar Belakang}

Pendidikan kesehatan ialah suatu kegiatan atau usaha yang optimal dalam membantu individu, keluarga, dan masyarakat untuk meningkatkan standard kesehatan yang baik. Petugas kesehatan mengakui bahwa program kesehatan ditunjang oleh pentingnya pendidikan kesehatan. Pada dasarnya pelaksanaan pengobatan dan pencegahan terhadap berbagai penyakit yang dialami oleh masyarakat merupakan tujuan utama dari pelayanan kesehatan masyarakat ini (Sudarmono, 2012).

Pada dasarnya semua layanan kesehatan haruslah di dasari ilmu yang didapat dari pendidikan dibidang kesehatan. Selayaknya sasaran pendidikan kesehatan merupakan perubahan kebiasaan perseorangan, keluarga, serta masyarakat dalam menjaga karakter sehat dan berperan aktif untuk tercapainya kesehatan yang optimum. Berdasarkan Nasrul Effendy yang dikutip dari bukunya yang dikutip dari steward, dalam buku tersebut ditulis pendidikan kesehatan merupakan komponen yang bertujuan merubah perilaku individu, keluarga serta masyarakat luas dengan tujuan membantu tercapai nya rencana rehabilitasi, pengobatan, peningkatan kesehatan dan pencegahan penyakit (Effendy, 1998).

Penjelasan diatas memiliki kesimpulan berupa bahwa tujuan Pendidikan yang paling pening didasarkan pada 3 pokok utama yaitu: (1) Munculnya perubahan perilaku pada individu, keluarga, kelompok, dan masyarakat dalam upaya melakukan Tindakan pembinaan dan pemeliharaan perilaku yang sehat dan menciptakan lingkungan sehat, serta memiliki peran serta yang aktif dalam upaya mewujudkan peningkatan taraf kesehatan yang baik serta optimal. (2) Membentuk sebuah pola perilaku hidup sehat dengan sasaran yang dimulai dari individu, keluarga, kelompok, dan masyarakat yang memiliki konsep perilku hidup sehat yang komprehensif dan hollistik mencakup fisik, social, dan mental guna menurunkan angka morbiditas dan mortalitas. (3) Pendidikan kesehatan menurut World Health Organization memiliki tujuan untuk merubah tabiat dan perilaku individu dan kelompok masyarakat dalam bidang kesehatan guna meningkatan taraf hidup kesehatan warga (Effendy, 1998).

Pendidikan kedokteran merupakan sebuah Pendidikan yang memakan waktu yang tidak singkat. Menurut ketentuan Kementerian Pendidikan dan Budaya bahwa seseorang dikatakan dapat menjadi dokter bilamana individu tersebut telah melewati kuliah tingkat Sarjana 1 atau tahap preklinik yang dalam penerapannya membutuhkan waktu kurang lebih selama 3,5 hingga 4 tahun dan haruslah pula melewati tahap Program Studi Pendidikan Profesi Dokter atau yang disebut tahap klinis dan "Co-as" yang ditempuh dalam waktu 20 hingga 24 bulan, serta melewati tahap akhir yang disebut Uji Kompetensi Mahasiswa Program Profesi Dokter (UKMPPD) sebelum dapat memperoleh gelar dokter atau "dr." Secara keseluruhan program profesi dokter dari awal masuk perkuliahan hingga mencapai gelar dokter membutuhkan waktu tidak kurang dari 5,5 tahun hingga 8 tahun. Perihal izin praktek seorang dokter tidak serta merta dapat segera terlaksana setelah menyelesaikan UKMPPD, tetapi harus menyelesaikan sebuah program yang dicanangkan oleh Kementerian Kesehatan yang disebut dengan program dokter internship yang membutuhkan waktu penyelesaian kurang lebih 1 tahun lamanya (Lestari, 2012).

Lamanya waktu Pendidikan dokter dengan segala rintangan yang ada membuat banyak mahasiswa hanya berhenti pada tahap-tahapan tertentu dari seluruh rangkaian Pendidikan dokter seperti setelah hanya menyelesaikan tahap sarjana-1 dan tidak mengikuti Program Studi Pendidikan Profesi Dokter (Fase klinik) yang berdampak terhadap gagalnya peserta didik untuk mencapai gelar dokter. Pada kasus lain, banyak pula kejadian dilapangan berupa peserta didik 
yang telah berhasil mengikuti Program Studi Pendidikan Profesi Dokter tetapi gagal selama 12 kali (3 tahun) pada tahap UKMPPD yang menyebabkan peserta didik tersebut di keluarkan dari kampus (drop out) dan gagal menjadi seorang dokter (Lestari, 2012).

Berkaca dari kasus diatas, terdapat banyak kasus dilapangan yang diketahui bahwa oknum yang belum menjadi dokter tersebut melakukan praktik kedokteran dalam sebuah klinik. Hal ini jelas dilarang oleh Hukum dikarenakan belum tercapainya standar kompetensi minimum yang dibutuhkan untuk menjadi seorang dokter yang berpraktek mandiri. Salah satu kasus terbaru yang terjadi dilapangan adalah kasus PT Kimia Farma Diagnostika, penyedia layanan rapid test di Bandara Soekarno Hatta, Tangerang, Banten, akan melaporkan oknum dokter yang melakukan pemerasan dan pelecehan seksual terhadap wanita di bandara tersebut ke polisi. Menurut penyeledikan mendalam diketahui bahwa oknum dokter yang berinisial EFYS bukanlah dokter yang tercatat dalam Konsili Kedokteran Indonesia (KKI). Konsili Kedokteran Indonesia (KKI) adalah badan atau Lembaga otonom yang bersifat independent, non-struktural, dan mandiri, serta memiliki tanggung jawab kepada pihak eksekutif (Presiden). Adapun tugas KKI adalah untuk melakukan registrasi terhadap seluruh dokter baik dokter umum dan dokter gigi yang bertugas di Indonesia, melakukan pengajaran serta pembinaan mengenai penyelenggaran praktik kedokteran dan menjamin serta meningkatan mutu akan pelayanan medis. Tidak tercatatnya EFYS dalam penelusuan laman Konsili Kedokteran Indonesia (KKI) membawa bukti terhadap bahwa EFYS bukanlah seorang dokter tetapi berpraktik layaknya sebagai seorang dokter (Hukmana, 2020).

Kasus diatas mungkin menyinggung beberapa masalah hukum terkait dimulai dari masalah pelecehan, penipuan, pemerasan, dan lain-lain. Makalah ini membatas pembahasan mengenai permasalahan kasus diatas hanyalah dari sudut pandang berupa aspek hukum pidanan terhadap oknum atau individu yang menggunakan identitas palsu sebagai seorang dokter. Bagaimana apek hukum penggunaan identitas palsu sebagai seorang dokter (dokteroid)? Bagaimana tindakan dan aspek hukum pidana pelaksanaan praktik kedokteran oleh dokter palsu (dokteroid)?

\section{METODE PENELITIAN}

Penelitian ini merupakan penelitian yang berbasis telaah pustaka (literature review). Pencarian pustaka berlangsung dari tanggal 20 September 2020 hingga 28 September 2020. Adapun pencarian data dilakukan di berbagai search engine seperti Google Scholar. Adapun kata kunci yang dipakai untuk mencari rujukan yaitu [["Hukum" OR "Tinjauan Yuridis"] AND ["Dokter Palsu" OR "Dokteroid"]]. Penelitian ini meninjau permasalahan strategis dari sudut pandang yuriditive normative. Beberapa sumber data yang digunakan dalam penelitian ini merupakan sumber data sekunder yang kredibel. Adapun sumber data sekunder dalam penelitian ini terbagi menjadi dua yaitu sumber pustaka dan sumber hukum sekunder. Sumber pustaka dalam penelitian ini meliputi buku, jurnal, dan dokumen tertulis lainnya. Bahan hukum sekunder yang digunakan dalam penelitian ini terdiri dari perundang-undangan yang berlaku, putusan pengadilan, teori hukum, doktrin, serta pendapat para ahli yang tersaji dalam bentuk dokumen tertulis.

Penelitian ini termasuk penelitian kualititatif, dimana seluruh bahan dan pustaka yang telah dikumpulkan selama periode penelitian akan ditelaah per bagian dengan 3 jenis pendekatan yaitu: (1) Pendekatan yuridis melalui penyesuaian dengan peraturan perundang-undangan yang berlaku (hukum positif di Indonesia); (2) Pendekatan konseptual yang mempertimbangkan pembahasan dari sisi sosiologi yang meliputi social budaya dan masyarakat; (3) Pendekatan analitis dengan mempertimbangkan hubungan dari berbagai aspek terkait yaitu sosial, budaya, kesehatan, dan hukum. Adapun Penelitian kualitatif dalam penelitian ini merupakan sebuah 
pendekatan dalam mensintesis data, pembahasan, dan kesimpulan data guna memberikan hasil yang terbaik (Ibrahim, 2006).

\section{PEMBAHASAN}

\section{Definisi, Tugas, dan Kompetensi Dokter}

Dokter merupakan seorang individu yang bekerja sesuai keilmuannya untuk menyembuhkan atau mengobati pasien atau orang yang dalam penyakit. Definisi dokter disini tidak berarti sebagai orang yang dapat menyembuhan segala penyakit, tetapi dengan pelatihan, Pendidikan, dan keilmuannya diharapkan dapat mengurangi penderitaan individu yang sakit (Soekiswati, 2019).

Definisi operasional dari "Dokter" merupakan tenaga kesehatan sebagai tempat tujuan pertama pasien dan petugas kesehatan untuk mengatasi semua permasalahan kesehatan yang terjadi tanpa memilih jenis penyakit, usia, organology serta jenis kelamin, secepat dan sebisa mungkin, dengan cara paripurna, menyeluruh, kolaborasi, dan koordinasi serta berkesinambungan bersama profesional kesehatan yang lainnya, menggunakan dasar pelayanan yang efisien dan efektif dan mengutamakan tanggungjawab hukum, profesional, moral dan etika. Layanan yang diselenggarakannya adalah sebatas kompetensi dasar kedokteran yang diperolehnya selama pendidikan kedokteran (konsil kedokteran indoensia, 2006).

Definisi dokter ditinjau Menurut Undang-Undang Nomor 29 Tahun 2004 tentang Praktik Kedokteran pada Pasal 1 ayat (2) ialah seluruh dokter baik umum, spesialis, gigi, dan gigi spesialis yang telah menelesaikan Pendidikan kedokteran di Indonesia maupun di luar negeri dan haruslah diakui oleh Pemerintah Indonesia dan mengacu pada perundang-undangan yang berlaku (Undang-Undang Nomor 29 Tahun 2004 Tentang Praktik Kedokteran, n.d.).

Dari pengertian sebelumnya dapat disimpulkan bahwa dokter merupakan individu yang mempunyai peran dan fungsi yang dapat membuktikan dirinya telah memenuhi dan melewati pendidikan dokter dengan baik diuar dan di dalam negeri yang dapat dibuktikan dengan surat ijazah atau surat keterangan lulus. Dengan kata lain individu yang disebut dokter tidak dari keahlian yang turun temurun, tetapi melewati jenjang pendidikan dokter.

Area kompetensi seorang dokter yang harus dicapai meliputi 7 area yaitu: (Konsil Kedokteran Indonesia, 2012).

1. Area akan kecakapan memberikan komunikasi yang efektif

2. Kompetensi untuk melaksanakan Keterampilan medis khususnya dibidang klinik dasar

3. Kemampuan untuk menerapkan ilmu pengetahuan biomedik, klinik, epidemiologi, serta perilaku dalam praktik medis.

4. Kemampuan untuk mengolah segala permasalahan kesehatan yang ada di tingkat individu hingga masyarakat dengan pendekatan yang komprehensif, holistik, bersinambung, terkoordinasi dan melakukan kolaborasi dengan berbagai tingkat fasilitas kesehatan

5. Mengelola informasi, menilai secara kritis dan memanfaatkan segala bentuk informasi yang didapat

6. Selalu mengembangkan diri dalam pembelajaran dengan motton belajar sepanjang hayat dengan menjunjung tinggi mawas diri

7. Praktik klinis yang selalu menjunjung profesionalisme, moral, dan etika yang berlaku 
Selain itu dokter juga memiliki tugas. Tugas yang diberikan kepada dokter merupakan: (Farida, 2009).

1. Membenahi masalah kesehatan individu, misalnya mendiagnosis penyakit, memeriksa pasien, melakukan konsultasi serta memberi pengobatan yang akurat, melakukan pencatatan, memberikan surat keterangan sehat, dan memberikan surat keterangan sakit

2. Dalam kondisi sehat maupun sakit pasien harus diberikan pelayanan yang baik.

3. Memberikan pertolongan pertama atau kegawatdaruratan kepada pasien sebelum ditransportasikan ke rumah sakit

4. Memberikan pelayanan rujukan kepada dokter yang lebih kompeten (dokter spesialis) untuk kelompok pasien yang membutuhkan pertolongan lebih.

5. Keluarga pasien diberikan bimbingan oleh dokter.

6. Dokter memiliki peran dalam kesehatan perseorangan, keluarga serta masyarakat

\section{Apek Hukum Penggunaan Identitas Palsu sebagai Seorang Dokter (Dokteroid)}

Hukum memiliki fungsi untuk menjaga, membuat kedamaian, dan ketertiban di dalam keseharian masyarakat. Hukum merupakan fasilitas yang diberikan kepada masyarakat untuk melindungi dirinya dari kegiatan individu lainnya yang berpotensi mengganggu dirinya. Penegakan hukum dapat dilaksanakan secara damai tetapi tidak menghilangkan kemungkinan terjadinya pelaggaran hukum. Oleh karena itu hukum harus ditetap ditegakan (Busroh, 2012).

Penegakan hukum adalah sesuatu yang harus diwujudkan untuk memberikan perlindungan dan kepastian hukum dalam masyarakat. Penegakan hukum di suatu negara haruslah berkaitan dengan tujuan negara yang berkaitan. Hal ini berarti, penegakan hukum haruslah sesuai kaidah, falsafah, prinsip dan pandangan hidup yang dihidupi oleh masyarakat, sehingga hal ini akan sesuai dengan gaya hidup masyarakat tersebut (C.S.T. Kansil, 2014).

Kitab Undang-Undang Hukum Pidana (KUHP) merupakan dasar hukum dari seluruh undangundang yang bersifat khsus dalam hal hukum pidana Indonesia. Akan lebih baik jika kita mengenal Kitab Undang-Undang Hukum Pidana (KUHP) terlebih dahulu sebelum mengenal hukum pidana (C.S.T. Kansil, 2014).

Penegakan hukum ialah bentuk usaha dalam menciptakan konsep dan ide menjadi kenyataan. Pada dasarnya penegakan hukum merupakan proses dalam mewujudkan cita-cita dan keinginan hukum di suatu tempat menjadi kenyataan. Maksud dari keinginan hukum ialah pikiran pembuat hukum atau undang-undang yang dibuat dalam hukum tersebut. Projeksi pikiran pembuat hukum (undang-undang) akan menentukan penegakan hukum di tempat yang terkait (Rahardjo, 1983).

Evaluasi penegakan hukum dapat dilihat dari seberapa jauh upaya yang dilakukan oleh penegak hukum dalam jangka waktu tertentu untuk mencapai tujuan hukum negara yaitu keadilan, dan seberapa besar nilai hukum yang telat diimplementasikan lewat penegakan hukum baik itu hukum proseduran ataupun hukum substantif (Muladi \& Arief, 1992).

Topik tentang penegakan hukum bukan hanya membicarakan bagaimana prosedur membuat hukum, melainkan juga tentang apa yang akan dilakukan petugas aparat dalam mengatasi dan mengantisipasi masalah-masalah pada penegakan hukum. Maka dari itu, dalam penanganan hukum pidana di dalam masyarakat bisa digunakan sarana hukum pidana dan tanpa hukum pidana (Muladi \& Arief, 1992). 
Penegakan hukum pidana memiliki 3 tahap, antara lain: (Muladi \& Arief, 1992).

1. Tahap Formulasi

Sebuhan tahap yang bertugas untuk membuat undang-undang (legislative). Peraturan atau hukum positif yang mengatur tindak pidana dari dokteroid (berperan sebagai dokter palsu) adalah Undang-Undang Nomor 29 Tahun 2004 Tentang Praktik Kedokteran.

2. Tahap Aplikasi

Tahap kebijakan merupakan tahap penerapan sebuah hukumdi tingkat apparat penegak hukum (polisi, tantara, dan pengadilan)Yaitu penerapan hukum pidana oleh aparat-aparat penegak hukum mulai dari kepolisian, TNI sampai pengadilan.

3. Tahap Eksekusi

Eksekusi merupakn pelaksanaan hukum secara nyata yang dilaksanakan oleh penegak hukum melalui sebuah proses ketetapan di pengadilan. Nama lain tahapan ini adalah tahapan administrative dan eksekutif. Tahap eksekusi dari tindak pidana dokteroid diatur pada Pasal 78 Undang-Undang Nomor 29 Tahun 2004 Tentang Praktik Kedokteran.

Teori Joseph Golstein berpendapat bahawa sebuah penegakan hukum terbagi menjadi 3 konsep besar berupa: (Muladi \& Arief, 1992).

1. Total enforcement concept memiliki tuntutan bahwa seluruh nilai yang berlaku dan berada di belakang norma hukum haruslah ditegakan secara keseluruhan tanpa terkecuali. Pandangan penegakan hukum ini dikenal sulit untuk dilaksanakan.

2. Full enforcement concept lahir dari kesadaran bahwa menyadari bahwa Total enforcement concept perlu dikendalikan dengan hukum acara sebagai sebuah bentuk perlindungan dari kepentingan individu.

3. Actual enforcement concept mulai muncul setelah keyakinan terhadap keberadaan akan deskripsi penegakan hukum bergantung terhadap adanya sarana-prasarana, partisipasi masyarakat, perundang-undangan, dan sumber daya manusia yang mumpuni.

Individu yang memiliki identitas palsu sebagai seorang dokter akan dikenakan hukum pidana oleh penegak hukum, karena tersangka telah terbukti melakukan tindakan pidana dan melanggar hukum Undang-Undang Nomor 29 Tahun 2004 Tentang Praktik Kedokteran. Adapun langkahlangkah penegakan hukum melalui upaya penal adalah sebagai berikut: (Husin \& Husin, 2012).

1. Penyelidikan

Rangkaian usaha penyelidik untuk menemukan dan mencari peristiwa yang diasumsikan sebagai tindak pidana untuk menentukan layak atau tidaknya untuk dilakukan penyelidikan berdasarkan cara yang teah ditentukan didalam UndangUndang.

2. Penyidikan

ialah serangkaian langkah penyidikan dalam mencari dan mengumpulkan bukti, bukti terkait akan digunakan untuk menindaklanjuti tindak pidana yang ditunjukan kepada tersangka.

3. Penuntutan

Ialah tindakan yang dilakukan oleh penuntut umum yang bertujuan menuntut perkara pidana kepada pengadilai negeri dengan prosedur yang diatur didalam UndangUndang yang akan dipertimbangkan dan diputuskan hakim di dalam sidang pengadilan.

4. Putusan Pengadilan

ialah pernyataan hakim yang ada dalam sidang pengadilan terbuka, yang dapat berupa pemidanaan atau bebas atau lepas dari segala tuntutan hukum. Dalam keputusan itu hakim akan menyatakan pendapat akhirnya tentang hal-hal yang telah 
dipertimbangkan dan apa yang telah menjadi keputusan, keputusan terkait disesuaikan dengan perkara pidana terkait yang telah dilakukan oleh tersangka.

\section{Tindakan dan Aspek Hukum Pidana Pelaksanaan Praktik Kedokteran oleh Dokter Palsu (Dokteroid)}

Dokter palsu yang melakukan Praktik Kedokteran yang ilegal akan dikenakan hukum pidana, penegakan hukum ini penting untuk memenuhi tujuan kepastian hukum dan rasa keadilan. Oleh karena itu, penegakan hukum penting dapat digunakan sebagai sarana menyamakan nilai dan norma yang tersebar di masyarakat dan melibatkan konsep yang terdapat pada penegakan hukum pidana (Soekiswati, 2019).

Undang-Undang Nomor 29 Tahun 2004 tentang Praktik Kedokteran yang telah dikeluarkan oleh pemerintah indonesia dijadikan pedoman untuk menangani kasus-kasus praktik dokter palsu yang terjadi agar tetap menjaga kualitas praktik dokter gigi dan dokter. pengendalian kualutas ini dilaksanakan sejak masa pendidikan, pemberian kewenangan dokter serta dokter yang telah berpraktik. Undang-Undang Nomor 29 Tahun 2004 tentang Praktik Kedokteran juga memiliki tujuan untuk menindaklanjuti praktik Ilegal yang dijalankan oleh dokter palsu.

Undang-Undang Nomor 29 tahun 2004 Mengenai Praktik Kedokteran, membahas pada Pasal 75 sampai pasal 80 berisikan uraian terhadap Pidana pokok terhadap pelanggaran ketentuan tertulis pada Pasal 29 (1), 31 (1), 32 (1), 36, 73 (1), 73 (2), 41 (1), 42, 46 (1), dan Pasal 51, yakni adanya ancaman kurungan selama 10) tahun atau denda uang senilai maksimal Rp. 300.000.000,00.

Sedangkan terkait peraturan pidana terhadap pelaksanaan praktik kedokteran yang illegal oleh dokter palsu didasarkan pada Undang-Undang Nomor 29 Tahun 2004 tentang Praktik Kedokteran Pasal 77 dan Pasal 78 yang berisikan adanya bukti pelanggaran terhadap ketentuan di Pasal 73 (1) dan 73 (2) dengan ancaman kurungan selama 5 tahun dan denda uang maksimal Rp. 150.000.000,00.

Perlindungan masyarakat untuk mencapai kesejahteraan merupakan tujuan akhir penegakan Hukum pidana, oleh karena itu penegakan hukum pidana merupakan bagian dari alat untuk mencapat kesejahteraan. maka normal jika dikatakan bahwa salah satu pembangunan nasional yang baik adalah upaya penyelesaian kasus kejahatan yang merupakan bagian dari hukum pidana (Sudarto, 1986).

Penegakan hukum yang dilakukan Dokter Ilegal merupakan hal penting. Hal ini berpengaruh karena penegakan hukum mempunyai tujuan untuk mencapai kepastian hukum serta rasa keadilan, maka penting untuk norma dan nilai di dalam masyarakat selaras dengan penegakan hukum yang dilakukan oleh Penegak hukum. Oleh karena itu, Dokter palsu yang melakukan praktik ilegal akan dikenakan hukum Penal dan hukum non-penal (Sudarto, 1986).

Penegakan hukum mengenai Praktik ilegal kedokteran yang telah dilakukan Dokter palsu, memiliki dua metode dalam penegakan hukumnya, yaitu cara yang lebih menegakkan pencegahan atau secara preventif dan cara yang lebih menekankan pemberantasan setelah telah terjadi tindak pidana (Sudarto, 1986).

Upaya represif merupakan usaha yang dilakukan penegak hukum untuk pemberantasan setelah kejahatan telah terjadi, yaitu dengan cara penerapan sanki pada pelakunya. tindakan represif ini memiliki kekurangan yaitu aparat penegak hukum harus bersikap pasif yang artinya harus menunggu laporan dari masyarakat bahwa adanya kerugian akibat praktik ilegal kedokteran, 
barulah akan dilakukan penyelidikan lebih lanjut. Namun pada kenyataannya masyarakat engga melaporkan kejadian praktik illegal ini karena akan berdampak langsung kepada masyarakat. oleh karena itu, lembaga berwewenang harus rutin melakukan razia dan pembinaan tentang praktik ilegal yang dijalankan oleh dokter palsu. Kemudian lembaga yang berwewenang harus bekerja sama dengan aparat penegak hukum untuk menindaklanjuti kasus dokter palsu yang telah melakukan praktik ilegal. hal ini dilakukan agak masyarakat terlindungi dari praktik ilegal. (Sudarto, 1986).

Sedangkan usaha preventif adalah usaha yang ditujukan untuk melakukan pencegahan sebelum terjadinya tindak kejahatan. Seperti yang tertulis pada Undang-Undang Nomor 29 Tahun 2004 tentang Praktik Kedokteran mengatur tentang segala bentuk syarat yang dibutuhkan untuk melaksanakan, memperoleh dan membuka izin praktik kedokteran ataupun ketentuan pidana yang berkaitan dengan kedokteran dan praktiknya, ini adalah salah satu bentuk usaha pemerintah untuk melakukan pencegahan kasus praktik ilegal kedokteran yang dilakukan oleh dokter palsu. selain itu usaha preventif dapat dilakukan berupa dilakukannya kegiatan sosialisasi/penyuluhan kepada masyarakat yang bertujuan agar masyarakat memiliki wawasan dan pengetahuan yang membedakan dokter asli dan dokter palsu, mauun praktik kedokteran yang yang berizin atau tidak. Pengetahuan ini diharapkan akan mengurangi terjadinya praktik ilegal dikarenakan masyarakat ikut serta berpartisipasi dalam usaha penegakan hukum, sehingga hal ini akan memudahkan aparat untuk mengatasi masalah dokter palsu (Sudarto, 1986).

\section{Faktor yang Berpotensi Menghambat Penegakan Hukum Pidana}

Teori yang dikemukakan oleh Soekanto menyatakan bahwa terdapat beberapa faktor yang berpotensi berpengaruh dalam penegakan hukum yatu: (Soekanto, 1983).

1. Faktor dari hukum dan perundang-undangan seperti adanya asas undang-undang yang tidak berlaku surat, undang-indang yang dibuat oleh penguasa, dan undang-undang dengan kedudukan superior.

2. Faktor aparat yang bertugas menegakan hukum

3. Faktor fasilitas, saran, dan prasarana yang didalamnya tercakup sumber daya manusia yang berpendidikan dan mumpuni serta terampil, sebuah organisasi yang baik, dana materiil yang cukup, dan ketersediaan peralatan yang mencukupi.

4. Faktor masyarakat dan lingkungan dimana penegakan hukum dilaksanakan

5. Faktor kebudayaan yang terdiri dari nilai-nilai dari sebuah hukum yang berlaku

Masyarakat memiliki peranan penting dalam proses penegakan hukum. Jika masyarakat tidak memberi informasi kepada kepolisian maka kepolisian akan kesulitan unuk memenuhi tugasnya untuk melakukan penegakan hukum. Pada kasus tindak pidana mengenai praktik illegal yang dilakukan oleh dokter palsu ini, masyarakat kurang mempunyai informasi untuk membedakan dokter asli atau dokter palsu (Soekanto, 1983).

Penulis berpendapat bahwa sikap kerjasama masyarakat sangat berpengaruh atas penuntasan kasus-kasus seperti itu. Karena masyarakat lah yang harus melaporkan apabia dokter tersebut adalah dokter palsu atau tidak. ini dikarenakan aparat penegak hukum tidak dapat melakukan penyelidikan jika tidak adanya laporan dari masyarakat yang telah tertulis pada KUHP. Oleh karena itu, jika masyarakat melaporkan praktik illegal yang dilakukan oleh dokter palsu maka selanjutnya aparat penegak hukum dapat melakukan tindakan lebih lanjut yaitu penangkapan, penyelidikan, penuntutan, hingga penjatuhan hukuman. Penjatuhan hukuman akan di dilakukan oleh hakim di kejaksaan. Aparat penegak hukum diharapkan mememiliki sikap profesionalisme agar dapat terselesaikannya kasus praktik illegal ini tanpa hambatan (Soekanto, 1983). 
Penegak hukum dapat menjadi faktor yang menghambat cepatnya penegakan hukum yang harus dijaduhkan kepada dokter palsu, hal ini dikarenakan ada aparat penegak hukum yang kurang profesional dalam menjalankan tugas dan kurangnya pengetahuan untuk mengatasi hal-hal yang berkaitan dengan praktik ilegal kedokteran. Beberapa lembaga berwenang kurang dapat bekerjasama dengan aparat penegak hukum. hal-hal lain yang mempengaruhi terhambatnya proses hukum adalah kurangnya fasilitas yang dapat memperlancar penegakan hukum. Tanpa adanya sarana dan prasarana yang baik maka akan berpotensi menghambat penegakan hukum (Soekanto, 1983).

Kebudayaan dapat dikatakan merupakan salah satu faktor yang dominan karena pada dasarnya profesi dokter merupakan profesi yang disukai oleh masyarakat. Menurut Nikmah Rosidah, dijelaskan bahwa faktor kebudayaan sebagai salah satu pendukung dan penghambat selesainya kasus ini merupakan norma dan nilai yang dianut oleh masyarakat. penghambat faktor budaya antara lain saat masyarakat tidak memiliki pengetahuan wewenang dan tugas dokter. Masyarakat juga mengganggap dokter merupakan profesi tidak bercela, sehingga masyarakat tidak berusaha melihat latar belakang pendidikan dokter yang terkait. Tetapi faktor kebudayaan juga dapat menjadi faktor yang dapat mempercepat selesainya kasus ini antara lain bahwa hal yang dilakukan dokter palsu tersebut melanggar norma dan nilai yang ada di dalam masyarakat, sehingga pelaku harus diberikan hukuman yang setimpal atas perbuatannya tersebut (Soekanto, 1983).

\section{KESIMPULAN DAN SARAN}

Jerat hukum yang dapat dipergunakan bagi seseorang yang menggunakan identitas palsu sebagai dokter diatur dalam Undang-Undang Nomor 29 Tahun 2004 Tentang Praktik Kedokteran. Penegakan hukum terhadap kasus dokter palsu yang melakukan praktik kedokteran menggunakan hukum pidana preventif yaitu pencegahan sebelum tidak kejahatan terjadi dengan sosialisasi dan pelatihan serta hukum pidana represif yang berupa Tindakan untuk memberantas kejahatan berdasarkan adanya laporan oleh masyarakat.

Pelanggaran hukum terhadap dokter palsu dan pelaksanaan praktik kedokteran adalah didasarkan pada Undang-Undang Nomor 29 tahun 2004 Mengenai Praktik Kedokteran, membahas pada Pasal 75 sampai pasal 80 berisikan uraian terhadap Pidana pokok terhadap pelanggaran ketentuan tertulis pada Pasal 29 (1), 31 (1), 32 (1), 36, 73 (1), 73 (2), 41 (1), 42, 46 (1), dan Pasal 51, yakni adanya ancaman kurungan selama 10) tahun atau denda uang senilai maksimal Rp. 300.000.000,00. Sedangkan terkait peraturan pidana terhadap pelaksanaan praktik kedokteran yang illegal oleh dokter palsu didasarkan pada Undang-Undang Nomor 29 Tahun 2004 tentang Praktik Kedokteran Pasal 77 dan Pasal 78 yang berisikan adanya bukti pelanggaran terhadap ketentuan di Pasal 73 (1) dan 73 (2) dengan ancaman kurungan selama 5 tahun dan denda uang maksimal Rp. 150.000.000,00

\section{REFERENSI}

Erwin, M., \& Busroh, F. F. (2012). Pengantar ilmu hukum. Rineka Aditama: Bandung.

Kansil, C. S. T., \& Christine, S. T. (2014). Pengantar ilmu hukum dan tata hukum Indonesia. Jakarta: Balai Pustaka.

Effendy, N., \& Asih, Y. (1998). Dasar-dasar keperawatan kesehatan masyarakat ( $1^{\text {st }}$ ed.). Jakarta: Penerbit Buku Kedokteran, EGC.

Farida, N. (2009). Medical professional ( $1^{\text {st }}$ ed.). Jakarta: Grasindo.

Hukmana, S. Y. (2020, September 20). Kasus pelecehan oleh dokter rapid test dibawa ke ranah hukum. Medcom.Id . https://m.medcom.id/nasional/hukum/zNPG1nAK-kasus- 
pelecehan-oleh-dokter-rapid-test-dibawa-ke-ranah-hukum?p=all.

Husin, K, \& Husin, B. R. (2012). Buku ajaran sistem peradilan pidana ( $1^{\text {st }}$ ed.). Bandar Lampung: Universitas Lampung.

Konsil Kedokteran Indonesia. 2006. Konsil Kedokteran Indonesia (KKI). Jakarta: Konsil Kedokteran Indonesia.

Konsil Kedokteran Indonesia. (2012). Standar kompetensi dokter Indonesia. Jakarta: Konsil Kedokteran Indonesia. http://www.kki.go.id/assets/data/arsip/SKDI_Perkonsil,_11_maret_13.pdf

Lestari, T. R. P. (2012). Kebijakan pendidikan kedokteran di Indonesia. Pusat Pengkajian, Pengolahan Data Dan Informasi (P3DI) Sekretariat Jenderal DPR RI, 4(8), 9-12. https://www.google.com/url?sa=t\&rct=j\&q=\&esrc=s\&source=web\&cd=\&cad=rja\&uact= 8\&ved=2ahUKEwiKzZzK0OTtAhW-

73MBHX9_DAQQFjAAegQIARAC\&url=https\%3A\%2F\%2Fberkas.dpr.go.id\%2Fpuslit $\% 2$ Ffiles\%2Finfo_singkat\%2FInfo\%2520Singkat-IV-8-II-P3DI-April-2012-

27.pdf\&usg=AOvVaw2s8C5dMg-DGZ0TzWdUjdQY

Muladi., \& Arief, B. N. (1992). Bunga rampai hukum pidana $\left(1^{\text {st }}\right.$ ed.). Bandung: Alumni.

Rahardjo, S. (1983). Masalah penegakan hukum: Suatu tinjauan sosiologis. Bandung: Sinar Baru.

Soekanto, S. (1983). Faktor-faktor yang mempengaruhi penegakan hukum. Bandung: Rajawali.

Soekiswati, S. (2019). Studi kritis praktik dokteroid paramedis pada pelayanan kesehatan. Media Keadilan: Jurnal Ilmu Hukum, 10(2), $111-\quad 131$. https://doi.org/10.31764/mk:\%20jih.v10i2.1968

Sudarmono, M. (2012). Pendidikan kesehatan. Semarang: FIK UNNES.

Sudarto. (1986). Kapita selekta hukum pidana. Bandung: Alumni.

JDIH BPK RI. Undang-undang nomor 29 tahun 2004 tentang praktik kedokteran. n.d. https://peraturan.bpk.go.id/Home/Details/40752/uu-no-29-tahun-2004 